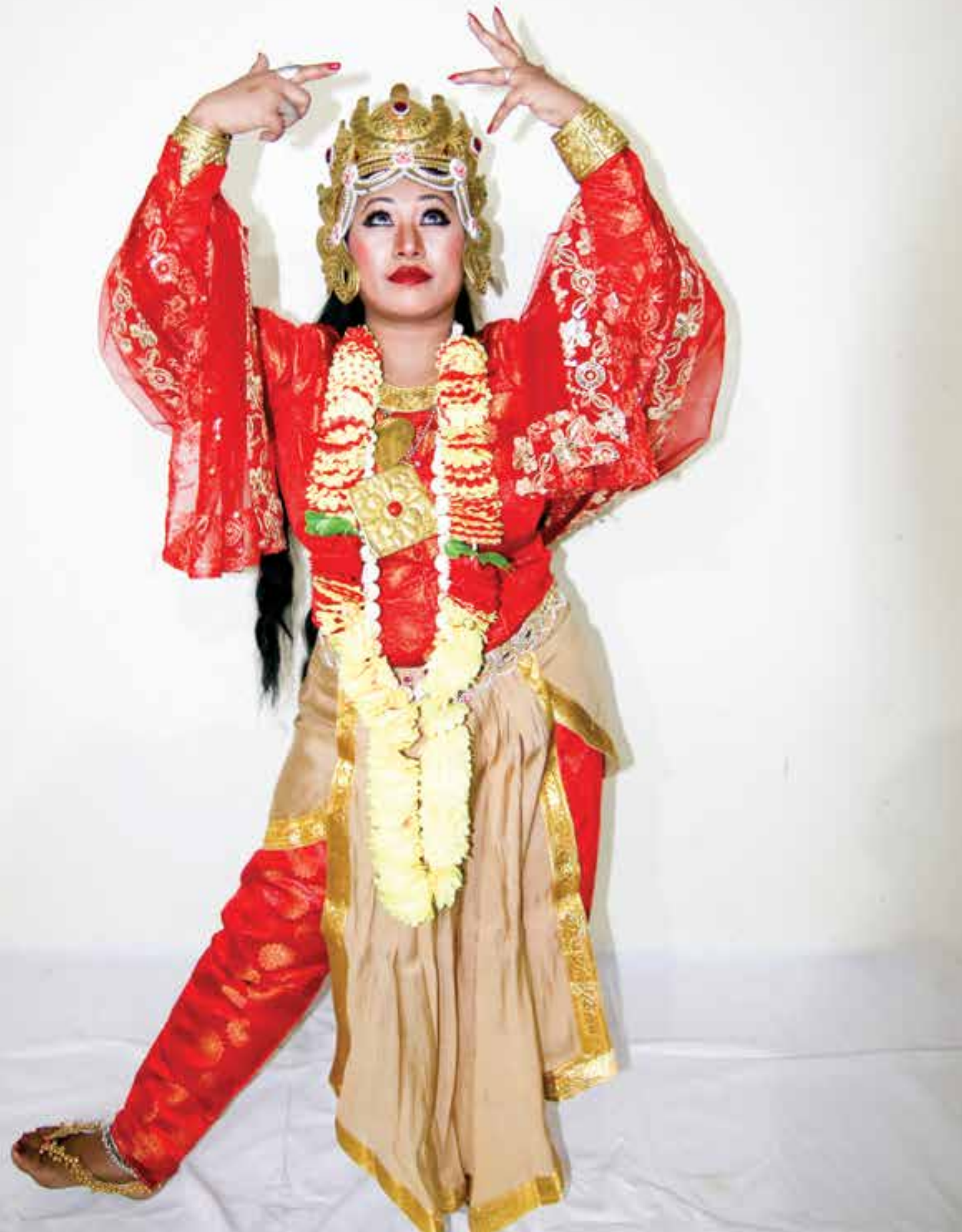

Caryā of Padasādhana being performed by Tara Manandhar (Head of the Depatment, Department of Music and Dance, SCoFA) 


\title{
CARYĀ OF PADASĀDHANA - A VAJRAYĀNA RITUAL
}

\section{Arun Shrestha}

\begin{abstract}
Padasädhana ritual or caryā is an alphabet of vajrayāna religion represented by twenty eight caryāgiti forming a major structure of the ritual performed. All the caryāgiti enacted during the ceremony is a climbing of steps one by one culminating in vajrapada. Construction of mandala, utterance of mantra and formation of mudra in course of worships are the pillars on which edifice of salvation is built. All the worships are based on mandala, mudra and mantra. What transpires for spiritual emancipation is through giti or song and nrtya or dance which is meant for visualization and ultimate realization of the set goal of the vajrayanna religion that is Buddhahood or Nirvāna.
\end{abstract}

Keywords: caryā, padasādhana, vajrayāna, Ahorātra Pūjā

\section{Introduction}

Caryā of Padasādhana has been named Ahorātra Pūjā or Ahorātrapadasādhanavidhi. The ritual ceremony names it Ahorātra Pūjā but the manual for execution of the ritual is titled as Ahorātrapadasādhanavidhi. On write up of the ritual, the word caryā necessitates inclusion along with padasādhana as the word caryā denotes 'practice' of the religion through a ceremony called padasādhana.

\section{Ahorātra Pūjā}

Ahorātra Pūjā is a three-weeks long ritual which begins with guru pūjā and mata pūjā, śrī nŗ̧tyanātha āhvāna pūjā, yodhakābhiśeşa pūjā and pịtha pūjā, mūlasiddhi pūjā and ultimately padasādhana pūjā. Padasādhana pūjā is followed by mañđala ālekha and adhivāsana, agni sthāpana, pūrņāhuti (rātrī guhya homa), raja pravāha (kaumārī tarpaña), chaturthī pūjā, yodhakābhiśeşa, śrī guhyehyeśvarī vana yātrā (vaňjalā), tvaňcchā pūjā and finally bhaşma pravāha.

All the worships or pūjās are performed by vajrācārya gubhājyus with designated responsibility assigned and these ācāryās carry a name decorated with the title namely mūlācārya, upādhyāya, karmācārya, pūrvācārya, paścimācārya, dakśināaārya, uttarācārya and host of others like thakālī, noku, svako, pyako, nyāko, khuko and nheko.

Some of the known names of vajrācāryas connected with Ahorātra Pūjās are śrī maňjudevācārya, śrī guñākar and śrī sāntikara who find mentioned in the ceremonies for the establishment of vihāra in vajrayāna literatures like kriyā 
saňgraha written by śrī jagadarpyaña, kriyāsamuccaya written by kuladatta and sambodaratantra. Vajrāvalī written by mahāpañđita Abhayakar is a major work on Ahorātra Pūjā.

Ahorātra Pūjā begins with construction of a mañđapa along with khambā, dvāra, toraña, nināla, dhvajā patākā and bitāna. Only those vajrācāryas who have undergone vajrācāryābhişeka and chaturdśābhişeka are eligible to perform the rituals. Entering the mañđapa these vajrācāryas perform kiraña koțaña through padasādhana. With an aim to impart anuttara gyāna to disciples, a piņđđikā maņđala and raja manđala is constructed according to nişpanna yogāvalī and then follows the tantric procedure of the ritual. To bring about peace to all the sentient beings, pratiśara pratāpa or flag, mārīci pratāpa and pratyaňgirā pratāpa is hoisted following the instruction in paňcarakśā pātha, mārīci tantra and pratyaňgirā tantra in the sequential order. After the flag hoisting, a yagya kunđa is dug for lakśa huti. Completion of the process of Ahorātra Pūjā necessitates the simultaneous playing of tūrya vāddha and accompanying gita or song and nrtya or dance, and on completion of the ritual, a path to Buddhahood is accessed, so it is believed and this is the aim of padasādhana ritual.

\section{Ahorātrapadasādhanavidhi}

Ahorātrapadasādhanavidhi, a hand written synopsis of the manual of the ritual of padasādhana by a karmācārya of the ceremony, presently referred to, is a referral to conduct the ritual consisting of worships and singing of series of caryāgīti and caryānŗ̧tya. The document of ahorātrapadasādhanavidhi consists of the different pūjā to be conducted, caryāgīti to be sung and caryānŗ̧ya to be performed. The procedure follows the sequence prescribed for the ritual of padasādhana. It begins with some of the worships and once basics required for the ceremony is set, a series of caryāgīti and caryānŗtya are mentioned to be sung and sang and danced to.

There are twenty-eight caryāgīti inscribed in ahorātrapadasādhanavidhi consisting of akāra sanjāta, anila, bhāsvarakhaņđa, cakrīkuņđala, dharadhara, dvambīnī, hāđābharana, haraśira, hum hum dehadharu, hūnkārasanjāta, jinajik, jinavarajananī, kolāi, madhyameru, namāmī 2 śrī heruka candra śekhara, namo hūm, namo hūm (repeat), nandinamaskāra, paramarato, rāgamālā, raktavarña, sūnyaniranjana, supratimaņđita, tribhuvana jvalita, trihaņđā, uragābharaña, viśvasaroruha and ye mahimañala in alphabetical order. Half of it is only to be sung and the other half is to be sang and danced to. Caryāgīti and caryānŗtya are to be sung and danced in a given sequential order. These twenty eight caryāgīti are guhya or secret caryāgīti performed in various rituals but they form a different combinations and sequences when rendered and performed as caryāgīti and caryāgītinŗtya in different rituals.

Caryāgīti and caryānŗtya are followed by series of pada or foot postures.

There are fourteen pada inscribed in ahorātrapadasādhanavidhi which is composed of āliđhapada, ekaśucika vajrapada, ekapada, jātapada, kurmapada, maņđalapad, pancaśucīka vajrapada, pratyāliđhapada, pravikatapada, samapada, vaiśāşapada, vajraśucika vajrapada, vīkatapada and viśvasucika vajrapada.

Āliđhapada and pratyāliđhapada are the main feet postures which has been used four times in the ritual process. Vaiśāşapada is the only one beside āliđhapada and pratyāliđhapada which has been used as many times.

Likewise, samapada and ekapada are used thrice; ekaśucika vajrapada, 


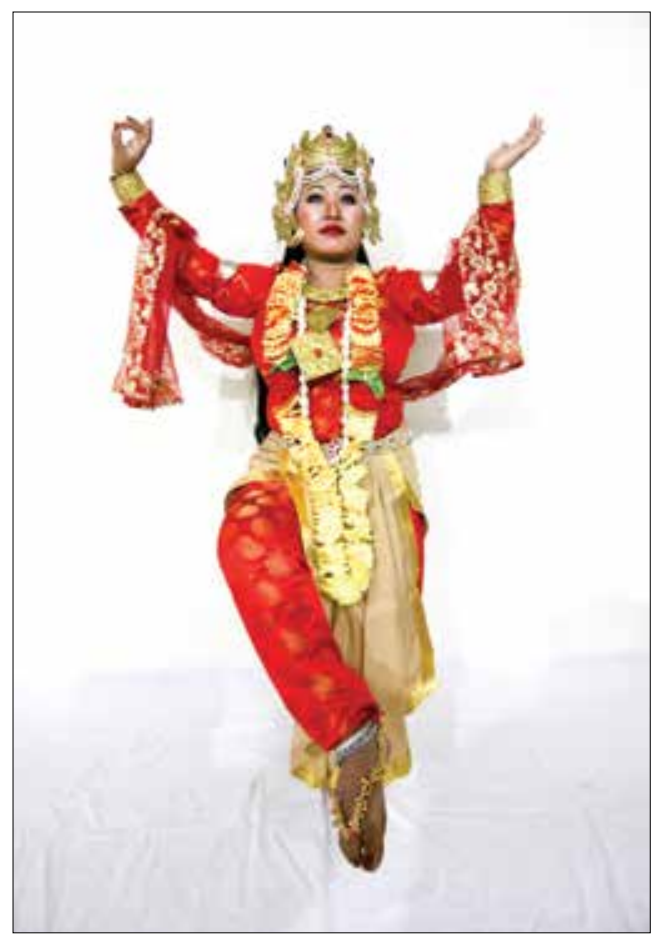

viśvaśucika.vajrapada, kurmapada and manđalapada has been used twice; and jātapada, vajraśucika vajrapada,pancaśucīka vajrapada, pravikatapada and vīkatapada has been used only once in the ritual process,

Variants of the sucika vajrapada are viśvaśucika vajrapada, ekaśucika vajrapada and pancaśucīka vajrapada.

Leaving aside āgney (south-east), three of the four direction of the space has been shown postured by āliđhapada in naitritya (south-west) and vāyutya (north-west) directions and by samapada in iśāne (north-east) direction.

Besides other pada, angātapada and upapada are also find mentioned Ahorātrapadasādhanavidhi manual does not describe the specific acts in detail but hints at the performances to be executed and its sequential timings. Categories can be defined as acts of worships and artistic execution of music and dance. Acts of worship encompasses performing different pūjā along with construction of mañđala, utterance of mantra and mudrā formations, besides sādhana, samādhi, abhişeka and śloka rendering. Among these acts, mudrā formation is the basic component of caryānŗtya and caryāgīti are the tool for sādhana.

\section{Caryā of padasādhana}

The title caryā of padasādhana has three important components e.g. caryā, pada and sādhana. Caryā amalgamates the worships performed in the ritual of which rendering of caryāgīti and execution of caryānŗtya is a part and parcel; pada formations are the ultimate aim at the physical level; and sādhana is the method of visualization of the deities and the realization of the doctrines put in for the emancipation of all the sentient beings in their path to being Buddha.

\section{Research Methodology}

The research is primarily based on a literature review of ahorātrapadasādhanavidhi handwritten manual of a vajrācārya gubhāju, written in Nepālabhāşā with devanāgarī script, who played a role of a karmācārya in the performance of the ritual of padasādhana in the year AD 1981. An accompanying manuscript of a collection of hundred caryāgīti, written in pracalita Newārī lipī, in use during the ritual and a printed publication of the ceremony details, in Nepālī with devanāgarī script, provided a strong backup for the research on caryā vis-à-vis vajrayāna Buddhism. Investigation into the subject matter of the literature required an acquaintance with pracalita Newārī lipī and devanāgarī script; knowledge of Nepālī and Nepālabhāşā languages along with Saňskrnta, some regional languages and so called Saňdhyābhāşā which required search into the literatures reviewed.

Long interaction with practicing 


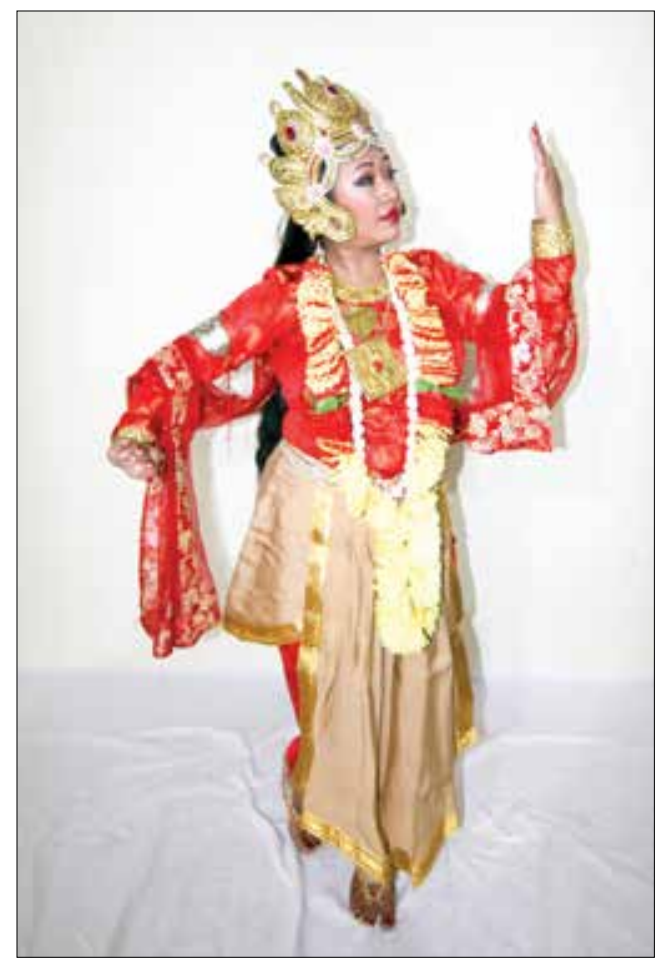

vajrācāryas was the beginning point of the dwelling in the subject chosen to probe and their feedback on vajrayāna religious knowledge and literary material support constituted the base of the work produced. Occasional observation of the ritual was a great booster in the improvement of the understanding of the religion and its practice.

Some published tantra literary work like guhyasamājatantra including caryāgītikoşa with few scholarly work on vajrayāna Buddhism formed a backdrop support for progress in the research work.

\section{Discussion}

Song and dance is the essential component of Caryā or practice of vajrayāna religion.

Song means caryāgīti and dance means caryānŗtya. Academic study of caryāgīti began with publication of caryāgītikoş containing fifty caryāgīti written by various siddha. The language of the gìti were claimed to be of Bengali origin. Collection of gìtī were discovered in Nepal but the origin had something else to tell, so it was thought. Many studies were carried out on the basis of the contents of caryāgitikoş. Study of the Nepalese caryāgìti were never taken up except a great work of compilation of caryāgiti in use by the vajrācāryas of the valley. It paved the way for investigation of the caryāgìti. The ones put into practice by vajrācārya of the valley had a different dimension in purpose of caryāgīti. They were written for practice of the ritual, and were sung in the rituals, whereas those in caryāgītikoşa collection seems to be written for propagation purpose of the vajrayāna religion. Though, subject matter of both the caryāgiti are the same. The language of the caryāgiti used in ritual practice by vajrācāryas is dominant in saňskŗ̦ta language with some regional languages, including so called saňdhyābhāşā, devoid of Nepālbhāşā. Surprisingly, none of the caryāgìti which were a part of caryāgîtikoş collection were in use for vajrācārya rituals except the one called trihaņđā .

Trihaņđā caryāgītinŗtya is one of those caryāgīti on which caryānŗtya is performed. The giti is also the only song contained in caryāgītikośa which finds its place in the vajrayāna ritual practice of vajrācārya of the Kathmandu valley. Trihanđđā is also known as strihanđā, tiađđā or trivrsttām. Trihaņđā and strihañđā is of Nepalese tradition, tiađđā is the expression found in caryāgītikośa and trivrsttām is the sanskkṛta version of the gìti by Munidatta. Meaning of Trihanđā, strihañđā and tiađđā mystically leads to feminine overtones but Munidatta's sanskrta version interprets trivṛttām as 'three nerves' or 'tina nāđi' specified as lalanā, rasanā and 


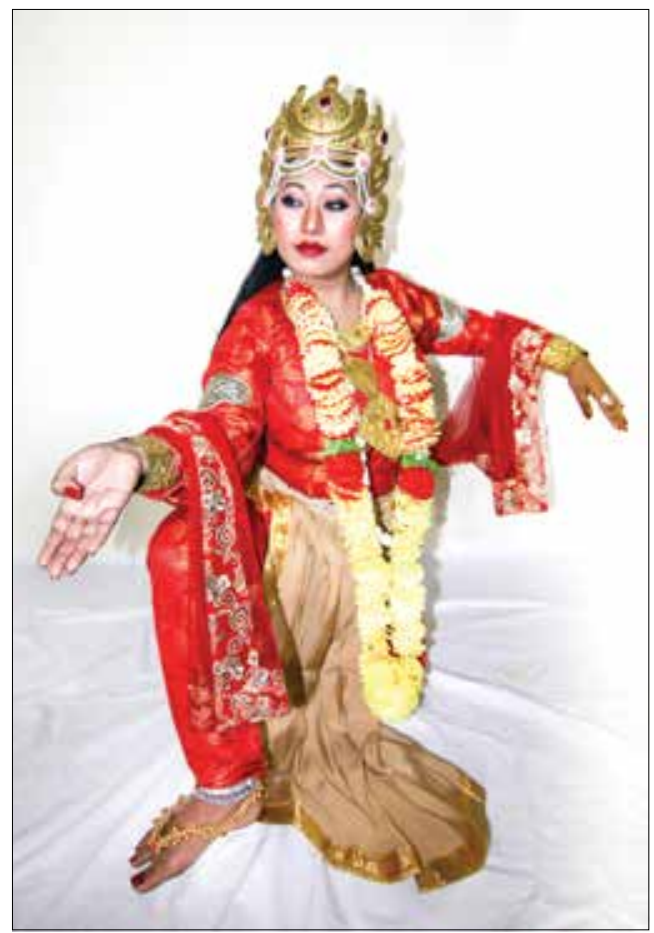

avadhūti. The act of caryā of trihanđā is indicative of the yoga process where the duality of lalanā and rasanā turns into non-duality or advaya form of avadhūti like merging of river gaňgā and jamunā into unseen or hidden sarasvati. The state of advaya is aimed at by the sādhana practiced as trihaņđā.

The deified god and goddess in the form of heruka and nairātma enact the drama to achieve mahāmudrā siddhi. In a symbolic way represented by trio of kamala, kuliśa, ghantha; duo of sun and moon; a yoga path leading to ođiyāna riding on manikula is indicated at. Possessing a state of yuganaddha or advaya in the embrace of masculine and feminine nature is the expression represented in the word kunduru, a so called saňdhyābhāşā word. The yoga process begins here in the sixteenth act of ahorātrapadasādhanavidhi, out of twenty-eight, in the name of trihañđā.
Kolāì, sang and danced in padasādhana, is the only caryāgīti which finds its place in vajrayāna text called hevajratantra.

Title of a caryāgīti is named on the basis of the first letter of the caryāgiti and this is the most mysterious and esoteric of all caryāgīti.

Caryā in essence means practice of the religion through worships or pūjās in a ritual of padasādhana but song or caryāgīti as well as dance or caryānŗtya are a must.

Series of caryānŗtya begins with hāđābharaa caryānŗ̧yagīta and ends with cakrikuñđala caryānŗtyagita finally culminating into series of pada which ends in vajrapada. These caryāgīti and caryānŗ̧tya capture small portion of the time consumed in the ritual of three weeks, as a song is rendered in few minutes time on which the dance is performed. But these caryāgīti or songs are used as a vehicle for the description of deities for sādhana in the worship to visualize and it also contains the philosophy of the religion for realization of the doctrine adhered to. In the sense of the philosophy and the doctrines contained in caryāgīti, caryāgīti are upanişad of vajrayāna religious philosophy. The philosophical songs on which the dance is performed, accompanied by the music, turns caryā of padasādhana into an aesthetic spiritualism. Caryāgīti is an essence of vajrayāna which is rendered with musical components and performed as a dance divine.

In the process of the ritual comprising of worships, songs and dance, sādhana is the binding factor which leads to emancipation envisaged and therefore it has been named caryā of padasādhana - worships, rendering of songs and execution of dance is a caryā reaching its crescendo in pada through sādhana.

Sādhanas are the tools for visualization of deities for the ultimate realization of 
the doctrine.

In vajrayāna Buddhism caryā or practice of the religion, sādhana plays a pivotal role of a vehicle on which sādhaka rides towards his journey of ultimate nirvāna. Buddhism is a godless religion but vajrayāna Buddhism abounds in pantheon of deities. These deities are nothing but manifestations which begins with paňcha skandha manifesting as paňch Buddha and all the other deities emanate from them.

Guhyasamājatantra very categorically specifies paňcabuddha to be nothing but paňcaskandha or basic elements human beings are composed of:

pancaskandhā samasena pancabuddhāh prakīrtitāh 1

vajra-āyatanānyeva

bodhisatvāgryamaņđalamiti 115011

guhyasamājatantra saptadasa pațalah p.111

The five skandha or paňcaskandha are proclaimed to be the five Buddha or paňcabuddha.

Gahyasamājatantra in its first chapter describes how other deities emanate in detail.

In the process of caryā or practice of the ritual, sādhaka becomes one with deities worshiped which is known as ahaňkāra in vajrayāna Buddhism, killing of ego and identifying one's self with the deity visualized.

In this ritual practice, sādhanas are the tools for visualization of deities for the ultimate realization of the doctrine and sādhanamālā is the garland of religious practice. Sādhanas are basically descriptive of deities which helps to meditate on deities for the worshiper to be one with. In this context, prachalita caryāgīti plays the role of sādhana through which a deity is visualized and those caryāgìtī sang and danced to in padasādhanavidhi are the basis for realization of the deity because they explain the philosophy and doctrine of the religion where as pracalita caryāgīti is mainly descriptive of the deity.

In the ultimate stage of the practice or caryā, the ritual of padasādhana turns out to be a yoga of vajrayāna or, in other words, şađaňga yoga of vajrayāna Buddhism.

\section{Findings}

Deities are mere manifestation of thought construction. An example referred to in guhyasamājatantra of paňca Buddha being manifestation of paňca skandha and emanation of all other deities of vajrayāna from paňca Buddha detailed in guhyasamājatantra suffices to establish vajrayāna as god-less religion in spirit as envisaged in its foundation.

Caryāgīti and caryānŗtyas are the main component of the rituals which are the specimen for the compilation of vajrayāna Buddhism doctrines as well as a tool of vajrayāna religious practice utilized for sādhana of symbolic manifested deities with higher goal of achieving emancipation, or in other word, nirvāñā.

Vajrayāna practice ultimately turns out to be practice of yoga or şađaňga yoga.

Art contained in caryā was never taken as for aesthetic presentation by religious practitioners but it oozes out for those who are drowned deep down.

Vajrayāna accepts the physical body as vehicle and point of departure for spiritual transmission.

Hand gestures or mudra, āsana, leg postures and body movements are defined but a systematic manual on dance finds missing.

Use of nepālbhāşā in caryāgītī contained in padasādhana is none existent despite its being practiced among Newār 


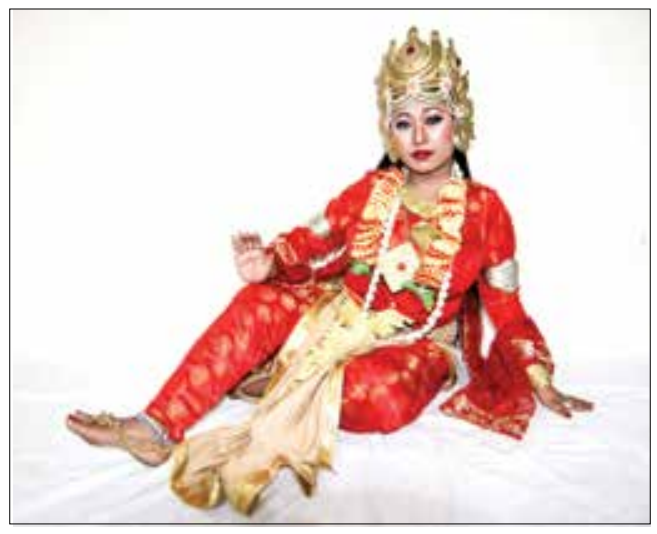

vajrācārya.

\section{Conclusion}

Buddhism arose out of opposition to yagya or homa but tends to entangle itself in once rejected practice. Ahorātrapadasādhana is one such example. Symbolism plays a prominent role in the practice of the religion and therefore leaning on to manifestations could be well understood but symbolic manifestations never replace the thoughts they represent. Therefore, the rituals like padasādhana are for realization of the symbolic manifestations presented in the form of deities for visualization through worships.

Caryāgīti and caryānŗtya incorporated in padasādhavidhi forms the essence of the practice or caryā as the crescendo of the ritual sums itself up with formation of vajrapada posture representative of the nrtya or dance comprised in the religious practice of vajrayāna.

And sādhana plays major role in the meditative practice which is a step towards achieving the goal of śađañga yoga inherent in vajrayāna spiritual aim.

The concept of ahaňkāra helps in transformation of sādhaka into sādhya or deity worshiped.

\section{Reference}

1. Documents:

Ahorātrapadasādhanavidhi. A hand written manual of padasādhana by the karmācārya of the ritual performed in 1981 at Vijayeşvarī.

Caryāgìti. A collection of 100 caryāgīti written in pracalita nevārī lipi referred to in the ritual by the Karmācārya.

2. Texts:

\section{Sādhanamā̄ā}

Sādhanamālā Vol. I. (1925). Edited by Benoytosh Bhattacharyya. Central Library. Baroda. Published by Newton Mohan Dutta of State Libraries for the Govt. of H. H. the Maharaja Gaekwad of Baroda.

Sädhanamālā Vol. II. (1928). Edited with an Introduction and Index by Benoytosh Bhattacharyya. Oriental Institute. Baroda. Gaekwad's Oriental Series.

\section{Caryāgīti-koşa}

Caryāgìti-koşa of Buddhist Siddhas. (1956). First Edition. Edited and Annonated by Prabodh Chandra Bagchi in collaboration with Śānti Bhikşu Śāstri. Visva-Bharati. Santiniketan.

\section{Guhyasamājatantra}

Guhyasamāja Tantra or Tathāgataguhyaka. (1984). Critically rdited by Swami Dwarikadas Shastri. Bauddha Bharati Series-17. Bauddha Bharati. Varanasi.

\section{Secondary sources:}

Bhattacharyya, Benoytosh. (1968). The Indian Buddhist Iconography. Mainly Based on The Sādhanamālā and Cognate Tāntric Texts of Rituals. Firma K. L. Mukhopadhyay. Calcutta.

Snellgrove, D. L. (1959). The Hevajratantra, A Critical Study. Part I. Introduction and Translation. Oxford University Press. London. 